\title{
Bulb Quality and Storability of Onion (Allium cepa L.) as Affected by Varieties and Intra-Row Spacing in Antsokia Gemza, Ethiopia
}

\author{
Birtukan Asmirew1,a Yohannes Gedamu, ${ }^{\text {,b }}$, Asrat Ayalew ${ }^{3, c, *}$ \\ ${ }^{1}$ Office of Agriculture, Antsokia Gemza District, Antsokia, Ethiopia \\ ${ }^{2}$ Department of Plant Sciences, College of Agriculture, Wollo University, 1145 Dessie, Ethiopia \\ ${ }^{3}$ Department of Horticulture, College of Agriculture and Environmental Sciences, University of Gondar, 196, Gondar, Ethiopia
} *Corresponding author

A R T I C L E I N F O
Research Article
Received : 13/09/2019
Accepted : 13/01/2020

A B S T R A C T

This experiment was conducted in Antsokia Gemza district, Ethiopia in 2017/18 to evaluate the effect of intra-row spacing on bulb quality and storability of onion varieties. A $4 \times 4$ factorial experiment with four different varieties (Adama Red, Bombay Red, Melkam and Shendi) and four levels of intra-row spacing $(5.00,7.50,10.00$ and $12.50 \mathrm{~cm})$ was laid on randomized complete block design with three replications. Data were collected on bulb quality attributes and storability and subjected to Analysis of Variance (ANOVA) using statistical analysis system (SAS) computer software 9.1. The mean separation test was done by list significant difference (LSD) test at 5\% probability level. Simple linear correlation analyses between and among the different parameters were made using Pearson Correlation Coefficient. Accordingly, most of the parameters were

Keywords:

Bulb yield

Ethiopia

Quality

Storability significantly affected by intra-row spacing and variety. Variety Melkam exhibited the highest bulb diameter, bulb length, bulb dry matter content and bulb fresh weight. Melkam and Adama Red were with the lowest weight loss in storage while Bombay Red and Shendi scored the highest weight loss in storage. Most of the bulb quality parameters were significantly highest at the widest intra-row spacing of 10.00 and $12.50 \mathrm{~cm}$. However, there was no significant variation between 7.50 and 10.00 $\mathrm{cm}$ intra-row spacing on average bulb weight which is considered as the most important bulb quality parameter for the producers from the market point of view. Weight loss was higher at the widest intra-row spacing for all varieties. Based on the findings of this study, it can be concluded that the bulb quality and storability of onion in Antsokia Gemza district can be optimized through cultivating variety Melkam at intra-row spacing of $7.5 \mathrm{~cm}$.

bdimpleas@gmail.com gizelekullu@gmail.com

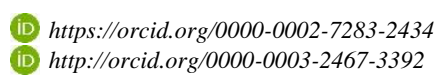

(iD) http://orcid.org/0000-0003-2467-3392 b@yohanchs@gmail.com

http://orcid.org/0000-0003-4979-3913

\section{Introduction}

Onion (Allium cepa L.) is one of the most important vegetable crops that are commercially grown in most parts of the world. It ranks second after tomato among vegetable crops produced in the world (FAO, 2017). It probably originated from Central Asia between Turkmenistan and Afghanistan where some of its relatives are still grown in the wild (Grubben and Denton, 2004; Bagali et al., 2012).

It is estimated that over 3.6 million ha of onions are grown annually around the world. On a worldwide scale, around 98.9 million metric tons of onions are produced per year (FAO, 2017). China is by far the top onion producing country in the world, accounting for approximately $25 \%$ of the world's onion production, followed by India, USA, Egypt, Iran, Russia, Turkey, Pakistan, Brazil, Bangladesh and South Korea.
Onion is a very important food and cash crop in Ethiopia predominantly grown by small holder farmers under small scale irrigation (Makombe et al., 2011). It occupies economically important place among vegetables in the country. Its area coverage increased by $29.63 \%$ from $2014 / 15$ to $2015 / 16$ mainly due to its high profitability per unit area and ease of production, and the increases in small scale irrigation areas. The total area coverage and annual production of onion in Ethiopia in 2015 was estimated to be 29.5 thousand ha and 265 thousand tons, respectively (CSA, 2016). In 2017, Ethiopia imported a net weight of 47.4 thousand tons of fresh or chilled onion and shallots from Sudan and exported around 16.5 thousand tons to Djibouti, Somalia and United States (ERCA, 2017). In Antsokia Gemza district, onion and tomato are among the predominately cultivated vegetable crops under irrigation. 
In 2017, about 2,250 ha of irrigated land had been covered by onion (AGWARDO, 2017).

In the past few decades, several screening and variety trials on a number of introduced onion varieties were carried out at Melkassa and other Agricultural Research Center. Consequently, few onion varieties, namely Rosy, Caramelo F1, Sweet Caroline, Red passion F1, Sivan, Jamber F1, Red king, Nafis Red, Neptune, Nasik Red, Adama Red, Red Creole, Bombay Red and Melkam, have been released for production (MARC, 2015). However, only three varieties, namely Adama Red, Bombay Red and Neptune are being supplied by seed retailers.

Optimum spacing and population density play important roles in contributing to high yield and better bulb quality. Because dense planting population will not get proper light for photosynthesis and may lead to high level of disease incidence while very small population will also reduce yield per unit area due to decreasing in light interception per unit area and excess vegetative growth (Pookpakdi and Pataradilok, 1993). The ideal spacing and plant population are those that maximize yield and quality without unduly increasing costs. As a rule, all crops tend to increase yield per unit area as plant population is increased, however up to a certain limit. Beyond this limit, the yield may not increase further and may even drop. The appropriate spacing for onion generally differs with differences in environment and variety (Rabinowitch and Brewster, 1990).

According to Awas et al. (2010) reported that control of plant spacing is one of the cultural practices to control bulb size, shape and yield. These authors also recommended intra-row spacing of $4 \mathrm{~cm}$ for Nasik Red and Adama Red and $6 \mathrm{~cm}$ for Bombay Red in Adami Tulu, Ethiopia. Zeleke and Derso (2015) also reported that spacing of $40 \mathrm{~cm}$ between double rows on a ridge, $20 \mathrm{~cm}$ between rows on the bed and $5-7 \mathrm{~cm}$ between plants is suitable for small scale hand operated production system.

However, all the studies are specific with regard to location and are relatively old and excluded the performance of varieties and population densities in potential onion growing areas like Antsokia Gemza district. In the study area, even most growers use narrower intra-row spacing, which is less than nationally recommended one. Therefore, to optimize quality onion productivity, site specific research based full package of information is required. Hence, this research was conducted to evaluate the effects of intra row spacing on bulb quality and storability of onion varieties in Antsokia Gemza district, Ethiopia.

\section{Materials and Methods}

\section{Description of the Study Site}

The field experiment was conducted at Atiko subdistrict of Antsokia Gemza District, North Shoa Zone, Eastern Amhara, Ethiopia, from November 2017 to April 2018 under furrow irrigation. The experimental site is located $310 \mathrm{~km}$ north east of Addis Ababa. It has an altitude of $1400 \mathrm{~m}$.a.s.l. and a bimodal unevenly distributed average annual rainfall of $900-1000 \mathrm{~mm}$ and the minimum and maximum temperature of $20^{\circ} \mathrm{C}$ and $29^{\circ} \mathrm{C}$, respectively. The $\mathrm{pH}$ of soil is 5.7-6.1 and it is fine sandy clay loam (AGWARDO, 2017). The area experiences less amount and erratic rainfall that stretches from March to June with the main rainy season from July to early September. In the area, rain fed agriculture is difficult due to moisture stress and drought, so using irrigation in dry season and supplementary irrigation in summer (meher) season is required to get good yield and quality bulbs.

\section{Description of the Experimental Materials}

Four nationally released onion varieties (Table 1) were collected from Melkassa and Humera Agricultural Research Centers for this study. These varieties differ in their bulb size (60-100 g), skin color (dark red, medium red and light red), leaf arrangement (erect and medium erect) and days to maturity (90-130 days).

\section{Treatments and Experimental Design}

A $4 \times 4$ factorial experiment with four onion varieties (Bombay Red, Adama Red, Melkam and Shendi) and four levels of intra-row spacing $(5,7.5,10$ and $12.5 \mathrm{~cm})$ was carried out in Randomized Complete Block Design (RCBD) with three replications. The plot size was $2.4 \mathrm{~m} \times$ $1.5 \mathrm{~m}\left(3.6 \mathrm{~m}^{2}\right)$ with $1 \mathrm{~m}$ spacing between blocks and $0.5 \mathrm{~m}$ between plots. Only the central rows were used for data collection. The plant density ranged from a minimum of 144 plants per plot ( $12.5 \mathrm{~cm}$ spacing) to a maximum of 360 plants per plot $(5 \mathrm{~cm}$ spacing).

\section{Nursery and Field Management}

Seedlings of each variety were raised on $1 \mathrm{~m} \times 5 \mathrm{~m}$ well prepared seed bed. The seeds were placed at the spacing of $10 \mathrm{~cm}$ between rows. All other nursery management practices such as mulching, watering, application of fertilizers, chemicals and weeding were applied as per recommendation for raising vigorous and healthy seedling of the crop. Seedlings were equally managed in nursery until transplanted to the main experimental area after 50 days.

Table 1. Characteristics of onion varieties used in the experiment

\begin{tabular}{l|llll}
\hline \multicolumn{1}{c|}{ Characteristics } & \multicolumn{1}{c}{ Adama Red } & \multicolumn{1}{c}{ Bombay Red } & \multicolumn{1}{c}{ Melkam } & \multicolumn{1}{c}{ Shendi } \\
\hline Leaf color & Medium Green & Dark Green & Dark Green & Medium Green \\
Leaf arrangement & Erect & Medium Erect & Erect & Medium Erect \\
Bulb size (g) & $60-80$ & $85-100$ & $70-90$ & $70-90$ \\
Bulb shape & Flat Globe & Flat Globe & High Globe & High Globe \\
Bulb skin color & Dark Red & Light Red & Medium Red & Light Red \\
Bulb flesh color & Redish White & Redish White & Redish White & Reddish White \\
Maturity (days) & $110-130$ & Less than 120 & $110-130$ & $90-110$ \\
Altitude (m) & $700-2000$ & $700-2000$ & $700-2000$ & $570-1500$ \\
Yield (tone/ha) & $9-15$ & $13-16$ & $9-15$ & $13-16$ \\
Source of varieties & MARC & MARC & MARC & HARC \\
\hline
\end{tabular}


Before transplanting, the experimental field was ploughed and harrowed. Large clods were broken down in order to bring the soil to fine tilth, and then 48 plots were prepared in which 16 plots were allocated in each replication. Moreover, ridges and rows were marked in each plot. One day before transplanting of seedlings, the nursery beds were irrigated for the safe uprooting of onion. Then, the seedlings were transplanted in well prepared and irrigated experimental field. During transplanting, only healthy, vigorous and uniform seedlings were transplanted and gap filling of the dead seedling was done within a week after transplanting.

Application of water was performed using furrow irrigation method. Four days irrigation interval was maintained for the first four weeks and then it was extended five to seven days interval until 15 days to harvest. Phosphorus was applied as Di Ammonium Phosphate (DAP) at the rate of $200 \mathrm{~kg} \mathrm{ha}^{-1}$ at the time of transplanting and nitrogen was applied in the form of urea at the rate of $150 \mathrm{~kg} \mathrm{ha} \mathrm{h}^{-1}$. Half of urea was applied at the time of transplanting, while the remaining was applied after four weeks of transplanting for all plots (EARO, 2004; SARC, 2008; Anisuzzaman et al., 2009).

The weeding was done with hand hoe and by handpulling whenever necessary throughout the experimental period to keep the crop free from weeds, for better soil aeration and to break the crust. Pest (Onion trips), leaf miner and disease (Purple blotch) were kept under control by applying Selecron (720 EC) $\left(0.51 \mathrm{ha}^{-1}\right)$, Dimethoate $(0.5$ $\left.1 \mathrm{ha}^{-1}\right)$ and Mancozeb $80 \mathrm{WP}\left(3 \mathrm{~kg} \mathrm{ha}^{-1}\right)$, respectively. These chemicals were applied in an interval of 3-5 days. Other agronomic practices were applied as per recommended for onion production.

\section{Data Collection}

Data related to bulb quality and storage life parameters were collected from 10 randomly selected bulbs from the net plot area. The harvested onion bulbs were cured for five days by wind rowing on the ground before topping. The procedure applied to collect the data is presented as follows.

Bulb diameter $(\mathrm{cm})$ : It was measured at right angles to the longitudinal axis at the widest circumference of the bulb in each plot using vernier caliper at harvest and the average was calculated.

Bulb length $(\mathrm{cm})$ : It is the vertical average length of the matured bulbs in each plot which was measured by vernier caliper.

Bulb neck thickness $(\mathrm{cm})$ : It was measured at the narrowest point at the junction of bulb and leaf sheath using a vernier caliper.

Average bulb weight $(g)$ : The average weight of bulbs of plants which were harvested from net plot was calculated as the mean fresh bulb weight after curing.

Bulb dry matter content (\%): from each plot, $200 \mathrm{~g}$ of fresh and chopped bulbs were dried in oven at $75^{\circ} \mathrm{C}$ for 48 hours to a constant weight to determine the dry matter content (DMC \%). It was calculated by using the formula:

$$
\operatorname{DMC}(\%)=\frac{\text { Sample oven dry weight }(\mathrm{g})}{\text { Sample fresh weight }(\mathrm{g})} \times 100
$$

TSS (total soluble solid): bulbs were cut horizontally through the center using sharp knife to collect the samples for determination of total soluble solid. The samples were then crushed gently in separate containers and drops of the juice were placed in a hand refractometer.

Bulb weight loss: Cumulative loss in weight was recorded at interval of two weeks for two months, keeping ten pre tagged bulbs from each plot spread on floor at ambient condition. It was calculated as per the following formula.

$$
\% \text { weight loss }=\frac{\mathrm{Wi}-\mathrm{Wf}}{\mathrm{Wi}} \times 100
$$

Where: $W_{\mathrm{i}}=$ initial weight, $W_{f}=$ final weight

\section{Data Analysis}

The data was subjected to Analysis of Variance (ANOVA) using SAS computer software 9 (SAS, 2008) and the mean separation test was done by Least Significant Difference (LSD) test at 5\% significance level. Simple linear correlation analyses among the different parameters were carried out using Pearson's correlation coefficient.

\section{Result and Discussion}

\section{Bulb Diameter $(\mathrm{cm})$}

The difference in bulb diameter per plant among varieties was highly significant $(\mathrm{P}<0.01)$ and very highly significant $(\mathrm{P}<0.001)$ among intra-row spacing while there was no significant interaction among the two main factors (Table 1).

According to Table 2, Melkam had the highest mean bulb diameter $(5.31 \mathrm{~cm})$ probably because it had highest plant height that resulted in higher photosynthetic area which help the variety accumulate food and turn out in higher bulb diameter. Melkam was followed by Bombay Red $(5.22 \mathrm{~cm})$ which was statistically similar with Adama Red $(5.04 \mathrm{~cm})$. The smallest mean diameter was measured from Shendi $(4.99 \mathrm{~cm})$ and Adama Red. This result agrees with the finding of Jambo (2015) who reported that Melkam variety had larger bulb diameter than Bombay Red and Adama Red.

The mean bulb diameter increased as intra-row spacing increased. Onion grown at $5 \mathrm{~cm}$ intra-row spacing had the lowest mean bulb diameter $(4.89 \mathrm{~cm})$ while the widest intra-row spacing $(12.5 \mathrm{~cm})$ had the highest mean bulb diameter $(5.4 \mathrm{~cm})$ (Table 2$)$.

The increase in bulb diameter with an increase in intrarow spacing can be attributed to reduced competition for nutrients and moisture at wider spacing. Onion plants grown at $5 \mathrm{~cm}$ intra-row spacing had fewest mean number of leaves which may explain why they have lower mean bulb diameter. The increases in bulb diameter as the intrarow spacing increases was also supported by Dawar et al. (2007) who indicated that onion grown at wider plant spacing had significantly bulb diameter while this yield component reduced at closer spacing due to less availability of soil nutrients, water and light etc.

\section{Bulb Neck Thickness}

The finding of this study revealed that intra-row spacing had significant $(\mathrm{P}<0.05)$ effect on bulb neck thickness. The interaction between these two factors did not have any effect on neck thickness (Table 1). 
Table 2. Effect of variety and intra-row spacing on bulb diameter (BD), bulb neck thickness (BNT), bulb length (BL) and average bulb weight (ABW) of onion

\begin{tabular}{|c|c|c|c|c|}
\hline Treatment & $\mathrm{BD}(\mathrm{cm})$ & $\mathrm{BNT}(\mathrm{cm})$ & $\mathrm{BL}(\mathrm{cm})$ & $\mathrm{ABW}(\mathrm{g})$ \\
\hline \multicolumn{5}{|c|}{ Variety } \\
\hline Adama Red & $5.04^{\mathrm{bc}}$ & 1.34 & $4.73^{b}$ & $70.20^{\mathrm{b}}$ \\
\hline Bombay Red & $5.22^{\mathrm{ba}}$ & 1.30 & $4.67^{b}$ & $78.14^{\mathrm{a}}$ \\
\hline Melkam & $5.31^{\mathrm{a}}$ & 1.35 & $5.00^{\mathrm{a}}$ & $80.98^{a}$ \\
\hline Shendi & $4.99^{c}$ & 1.31 & $4.93^{\mathrm{a}}$ & $75.81^{\mathrm{ab}}$ \\
\hline $\operatorname{LSD}(5 \%)$ & 0.19 & ns & 0.18 & 5.78 \\
\hline \multicolumn{5}{|c|}{ Intra-row $(\mathrm{cm})$} \\
\hline 5.00 & $4.89^{\mathrm{b}}$ & $1.26^{\mathrm{b}}$ & $4.71^{b}$ & $68.68^{c}$ \\
\hline 7.50 & $5.03^{b}$ & $1.31^{\mathrm{ab}}$ & $4.79^{\mathrm{ab}}$ & $75.03^{\mathrm{b}}$ \\
\hline 10.00 & $5.24^{\mathrm{a}}$ & $1.35^{\mathrm{ab}}$ & $4.86^{\mathrm{ab}}$ & $78.54^{\mathrm{ab}}$ \\
\hline 12.50 & $5.40^{\mathrm{a}}$ & $1.38^{\mathrm{a}}$ & $4.97^{\mathrm{a}}$ & $82.87^{\mathrm{a}}$ \\
\hline $\operatorname{LSD}(5 \%)$ & 0.19 & 0.09 & 0.18 & 5.78 \\
\hline Mean & 5.14 & 1.32 & 4.83 & 76.28 \\
\hline $\mathrm{CV}(\%)$ & 4.52 & 8.28 & 4.45 & 9.1 \\
\hline
\end{tabular}

Slightly higher bulb neck thickness was observed from Melkam $(1.35 \mathrm{~cm})$ and Adama Red $(1.34 \mathrm{~cm})$ than Bombay Red $(1.3 \mathrm{~cm})$. The numerical difference occurred, because the trait was influenced by growing area and the interaction of cultivar and environment. In addition, slightly thicker bulb neck $(1.38 \mathrm{~cm})$ was observed in plants spaced in 12.5 $\mathrm{cm}$ than plants spaced at the narrower intra-row spacing. On the other hand, the lowest neck thickness $(1.26 \mathrm{~cm})$ was observed with $5 \mathrm{~cm}$ intra-row spacing (Table 2).

The general trend in this study showed that the neck thickness increased as the intra-row spacing increased from 5 to $12.5 \mathrm{~cm}$ (Table 2). The present study is in agreement with the report of Dawar et al. (2007) who reported that onion grown at wider plant spacing had significantly increased of bulb neck thickness while at closer spacing this yield component was reduced.

\section{Bulb Length}

The effect of variety on bulb length was very highly significant $(\mathrm{P}<0.001)$ and intra-row spacing had significant $(\mathrm{P}<0.05)$ effect on bulb length; however their interaction did not show a significant variation (Table 1).

Considering mean performance of varieties, Melkam and Shendi gave the longest bulb length $(5.00 \mathrm{~cm}$ and $4.93 \mathrm{~cm}$, respectively) while variety Bombay Red $(4.67 \mathrm{~cm})$ and Adama Red $(4.73 \mathrm{~cm}$ ) had the shortest bulb length (Table 2).

Contrary to this study, Demisie and Tolessa (2018) reported that Adama Red gave the longest $(5.85 \mathrm{~cm})$ bulb length while variety Melkam had the shortest $(5.09 \mathrm{~cm})$ bulb length. The trait could be influenced by growing area and the interaction of cultivar and environment.

Bulb length increased as intra-row spacing increased (Table 2). The highest bulb length $(4.97 \mathrm{~cm})$ was recorded at the widest intra-row spacing while the narrowest intrarow spacing resulted in the lowest $(4.71 \mathrm{~cm})$ bulb length. This could be attributed to reduced limitations of growth factors at wider spacing that allows the bulbs to have more assimilates available for storage and thus resulted in higher bulb length. Asres (2017) also reported that higher bulb length $(6.02 \mathrm{~cm})$ was observed in wider spacing $(15 \mathrm{~cm})$ followed by those planted at $12.5 \mathrm{~cm}$ while significantly smaller bulb length $(5.48 \mathrm{~cm})$ was obtained from closer spacing $(7.5 \mathrm{~cm})$, which was also statistically similar to those planted at $10 \mathrm{~cm}$ spacing.

\section{Average Bulb Weight (g)}

According to the analysis of variation, variety had highly significant effect $(\mathrm{P}<0.01)$ on bulb fresh weight and intra-row spacing had very highly significant $(\mathrm{P}<0.001)$ effect on same parameter (Table 1). However, there was no significant interaction effect between varieties and intrarow spacing.

Melkam had significantly higher mean bulb fresh weight (80.98 g) than Adama Red (70.2 g) (Table 2). In concurrence to the present study, Kahsay et al. (2013) reported that Melkam had the highest bulb weight (75.77 g) as compared to Adama Red, Bombay Red and Nasik Red. Jambo (2015) also reported that Melkam had the highest fresh bulb weight (68.33 g) which exceeded Bombay Red and Adama Red by 11 and 29\%, respectively.

The fresh weight of the bulb increased by $21 \%$ as the intra-row spacing increased from $5 \mathrm{~cm}$ to $12.5 \mathrm{~cm}$ (Table 2). The highest bulb diameter recorded from the widest intrarow spacing, probably as a result of availability of more resources at this spacing, may contribute to the increase in bulb fresh weight. In agreement with this study, Jambo (2015) reported that mean fresh bulb weight increased as intra-row spacing increased from 4 to $10 \mathrm{~cm}$ by about $47 \%$.

\section{Bulb Dry Matter Content}

The effect of variety on bulb dry matter content was very highly significant $(\mathrm{P}<0.001)$ and the interactions between variety and intra-row spacing was significant $(\mathrm{P}<0.05)$ (Table 2).

Varieties were responded differently at different intrarow spacing. On plots with an intra-row spacing of 5, 7.5 and $10 \mathrm{~cm}$, bulb dry matter content of Adama Red, Melkam and Shendi were not statistically different, however significantly higher than that of Bombay Red. At intra-row spacing of $12.5 \mathrm{~cm}$, bulb dry matter content of Bombay Red was statistically similar with that of Melkam and Shendi (Table 3). The lowest bulb dry matter content (BDMC) from Bombay Red may be associated with its rapid bulbing property. This result is similar with the report of Kahsay et al. (2013) who confirmed that lowest dry matter content is recorded from Bombay Red.

On the other hand, intra-row spacing was also had different effects on different onion varieties. Significantly highest BDMC of Bombay red was recorded from the 
wider intra-row spacing $(12.5 \mathrm{~cm})$ while there was no statistically significant difference among all intra-row spacing using Adama Red, Melkam and Shendi. The highest BDMC of Bombay Red at the widest intra-row spacing may due to less competition for light and mineral which may enhance growth and synthesis of more photoassimilates to be translocated in to bulbs.

\section{Total Soluble Solid}

Both variety and intra-row spacing had very highly significant effect on total soluble solid of onion bulbs. The interaction between the main factors had significantly $(\mathrm{P}<0.05)$ influenced the total soluble solid of the onion bulbs (Table 1).

The effect of varieties on total soluble solid (TSS) varied as the intra-row spacing varies. At the narrowest intra-row spacing $(5 \mathrm{~cm})$ and widest intra-row spacing $(12.5 \mathrm{~cm})$ statistically similar and significantly highest TSS was recorded from Adama Red, Melkam and Shendi while significantly the lowest TSS was recorded from Bombay Red. At $7.5 \mathrm{~cm}$ intra-row spacing, significantly highest TSS was recorded from Adama Red and Melkam while significantly the lowest TSS was recorded from Bombay
Red. At $10 \mathrm{~cm}$ intra-row spacing, significantly highest TSS was obtained from Melkam compared to Shendi and there was no significant difference among Adama Red, Bombay Red and Shendi (Table 3).

Similarly, the effect of intra-row spacing on TSS varied on the different varieties of onion. Using Adama Red, although there was no statistically significant difference among 5, 7.5 and $12.5 \mathrm{~cm}$ intra-row spacing, the highest TSS (13.53 ${ }^{\circ}$ Brix) was recorded from the narrowest intrarow spacing $(5 \mathrm{~cm})$. Using Bombay Red, although there was no statistically significant difference among 5, 7.5, and $12.5 \mathrm{~cm}$ intra-row spacing, the lowest TSS was obtained from the widest intra-row spacing $(12.5 \mathrm{~cm})$. Melkam produced significantly highest TSS of $13.33{ }^{\circ}$ Brix at the narrowest intra-row spacing $(5 \mathrm{~cm})$ compared to $12.5 \mathrm{~cm}$. Using Shendi, significantly highest TSS was recorded from the narrowest intra-row spacing than the other intra-row spacing (Table 3 ).

Even though the trend was not consistent due to interaction effects, the highest TSS was recorded from Adama Red and Melkam while the lowest one is from Bombay Red. Similar to this result, Kahsay et al. (2013) also reported that Adama Red and Melkam had highest TSS.

Table 3. Interaction effect of variety and intra-row spacing on bulb dry matter content $(\%)$ of onion

\begin{tabular}{|c|c|c|c|c|c|c|c|c|c|c|}
\hline \multirow{2}{*}{$\begin{array}{c}\text { Intra-row } \\
\text { spacing }(\mathrm{cm})\end{array}$} & \multicolumn{5}{|c|}{ Total soluble solid ( ${ }^{\circ}$ brix $)$} & \multicolumn{5}{|c|}{ Dry matter content $(\%)$} \\
\hline & 5.00 & 7.50 & 10.00 & 12.50 & Mean & 5.00 & 7.50 & 10.00 & 12.5 & Mean \\
\hline \multicolumn{11}{|c|}{ Varieties } \\
\hline Adama Red & $13.53^{\mathrm{a}}$ & $12.60^{\mathrm{ab}}$ & $11.57^{\mathrm{bcd}}$ & $12.17^{\mathrm{abc}}$ & 12.47 & $17.08^{\mathrm{ab}}$ & $16.66^{\mathrm{ab}}$ & $17.33^{\mathrm{ab}}$ & $17.8^{\mathrm{a}}$ & 17.22 \\
\hline Bombay Red & $9.80^{\mathrm{ef}}$ & $10.67^{\text {def }}$ & $10.87^{\text {cde }}$ & $9.47^{\mathrm{f}}$ & 10.20 & $14.00^{\mathrm{c}}$ & $14.00^{\mathrm{c}}$ & $14.08^{c}$ & $16.30^{\mathrm{b}}$ & 14.60 \\
\hline Melkam & $12.93^{\mathrm{ab}}$ & $12.17^{\mathrm{abc}}$ & $12.17^{\mathrm{abc}}$ & $11.07^{\mathrm{cde}}$ & 12.09 & $16.61^{\mathrm{ab}}$ & $17.80^{\mathrm{a}}$ & $17.66^{\mathrm{a}}$ & $16.86^{\mathrm{ab}}$ & 17.23 \\
\hline Shendi & $13.33^{\mathrm{a}}$ & $11.83^{\mathrm{bcd}}$ & $10.67^{\mathrm{def}}$ & $11.07^{\text {cde }}$ & 11.73 & $16.16^{\mathrm{b}}$ & $16.55^{\mathrm{ab}}$ & $16.65^{\mathrm{ab}}$ & $16.11^{\mathrm{b}}$ & 16.37 \\
\hline \multirow[t]{2}{*}{ Mean } & 12.40 & 11.82 & 11.32 & 10.95 & & 15.96 & 16.25 & 16.43 & 16.77 & \\
\hline & \multicolumn{5}{|c|}{$\operatorname{LSD}(5 \%)=1.37, \mathrm{CV}(\%)=7.08$} & \multicolumn{5}{|c|}{$\operatorname{LSD}(5 \%)=1.29 \mathrm{CV}(\%)=4.74$} \\
\hline
\end{tabular}

Means with the same letter(s) within columns and rows are not significantly different according to LSD test at $5 \%$ level of significance

Table 4. Interaction effect of variety and intra-row spacing on weight loss (\%) at second and fourth week of storage

\begin{tabular}{|c|c|c|c|c|c|c|c|c|c|c|}
\hline \multirow{2}{*}{$\begin{array}{l}\text { Intra-row } \\
\text { Spacing }(\mathrm{cm})\end{array}$} & \multicolumn{5}{|c|}{ Second week } & \multicolumn{5}{|c|}{ Fourth week } \\
\hline & 5 & 7.5 & 10 & 12.5 & Mean & 5 & 7.5 & 10 & 12.5 & Mean \\
\hline \multicolumn{11}{|c|}{ Varieties } \\
\hline Adama Red & $1.65^{\mathrm{g}}$ & $2.69^{\mathrm{ef}}$ & $2.13^{\mathrm{fg}}$ & $5.89^{a}$ & 3.09 & $4.93^{\mathrm{ef}}$ & $5.73^{\mathrm{efd}}$ & $4.81^{\mathrm{f}}$ & $5.91^{\text {cdef }}$ & 5.35 \\
\hline Bombay Red & $3.24^{\mathrm{cde}}$ & $3.19^{\mathrm{de}}$ & $4.11^{b}$ & $3.97^{\mathrm{bc}}$ & 3.63 & $7.96^{\mathrm{ab}}$ & $7.02^{\mathrm{bcd}}$ & $7.97^{\mathrm{ab}}$ & $8.77^{\mathrm{a}}$ & 7.93 \\
\hline Melkam & $2.92^{\mathrm{de}}$ & $2.90^{\mathrm{de}}$ & $3.37^{\text {cde }}$ & $3.09^{\mathrm{de}}$ & 3.07 & $5.24^{\mathrm{ef}}$ & $5.45^{\mathrm{ef}}$ & $4.75^{f}$ & $5.13^{\mathrm{ef}}$ & 5.14 \\
\hline Shendi & $3.41^{\text {bcde }}$ & $2.92^{\mathrm{de}}$ & $3.15^{\mathrm{de}}$ & $3.55^{\mathrm{bcd}}$ & 3.26 & $5.47^{\mathrm{ef}}$ & $6.13^{\text {cde }}$ & $8.66^{\mathrm{a}}$ & $7.17^{\mathrm{bc}}$ & 6.86 \\
\hline \multirow[t]{2}{*}{ Mean } & 2.81 & 2.93 & 3.19 & 4.13 & & 5.9 & 6.08 & 6.55 & 6.75 & \\
\hline & \multicolumn{5}{|c|}{$\mathrm{CV}(\%)=13.31 ; \operatorname{LSD}(5 \%)=0.72$} & \multicolumn{5}{|c|}{$\mathrm{CV}(\%)=12.47 ; \operatorname{LSD}(5 \%)=1.31$} \\
\hline
\end{tabular}

Means with the same letter(s) within columns and rows are not significantly different according to LSD test at $5 \%$ level of significance

Table 5. Interaction effect of variety and intra-row spacing on weight loss $(\%)$ at sixth and eighth week of storage

\begin{tabular}{|c|c|c|c|c|c|c|c|c|c|c|}
\hline \multirow{2}{*}{$\begin{array}{c}\text { Intra-row } \\
\text { Spacing }(\mathrm{cm})\end{array}$} & \multicolumn{5}{|c|}{ Sixth week } & \multicolumn{5}{|c|}{ Eighth week } \\
\hline & 5 & 7.5 & 10 & 12.5 & Mean & 5 & 7.5 & 10 & 12.5 & Mean \\
\hline \multicolumn{11}{|c|}{ Varieties } \\
\hline Adama Red & $9.15^{\mathrm{f}}$ & $10.67^{\text {cdef }}$ & $10.69^{\text {cdef }}$ & $11.68^{\mathrm{bcd}}$ & 10.55 & $13.99^{\mathrm{ef}}$ & $14.90^{\mathrm{edf}}$ & $15.63^{\text {bcde }}$ & $16.64^{\mathrm{bcd}}$ & 15.29 \\
\hline Bombay Red & $10.23^{\mathrm{def}}$ & $12.08^{\mathrm{b}} \mathrm{c}$ & $12.66^{\mathrm{b}}$ & $15.61^{\mathrm{a}}$ & 12.65 & $14.73^{\mathrm{def}}$ & $16.14^{\text {bcde }}$ & $17.77^{\mathrm{b}}$ & $21.92^{\mathrm{a}}$ & 17.64 \\
\hline Melkam & $9.73^{\text {ef }}$ & $10.73^{\text {cdef }}$ & $9.72^{\mathrm{ef}}$ & $10.10^{\mathrm{def}}$ & 10.07 & $13.96^{\mathrm{ef}}$ & $13.96^{\mathrm{ef}}$ & $12.87 f$ & $12.83^{\mathrm{f}}$ & 13.41 \\
\hline Shendi & $10.79^{\text {cde }}$ & $11.54^{\mathrm{bcd}}$ & $12.11^{\mathrm{bc}}$ & $12.81^{\mathrm{b}}$ & 11.81 & $15.67^{\text {bcde }}$ & $15.24^{\text {cdef }}$ & $16.86^{\mathrm{bcd}}$ & $17.37^{\mathrm{bc}}$ & 16.29 \\
\hline \multirow[t]{2}{*}{ Mean } & 9.98 & 11.26 & 11.3 & 12.55 & & 14.59 & 15.06 & 15.78 & 17.19 & \\
\hline & \multicolumn{5}{|c|}{$\mathrm{CV}(\%)=8.75 ; \operatorname{LSD}(5 \%)=1.64$} & \multicolumn{5}{|c|}{$\mathrm{CV}(\%)=9.37 ; \operatorname{LSD}(5 \%)=2.45$} \\
\hline
\end{tabular}


With respect to intra-row spacing, the highest TSS was obtained at the narrowest intra-row spacing while the lowest TSS was recorded from wider intra-row spacing. This might due to dilution of TSS as larger bulbs grown at wider spacing have higher volume and more water content. This result is in agreement with the report of ARDC (2008) and Mallor et al. (2011) who reported that higher bulb size resulted in lower TSS.

\section{Bulb Weight Loss}

Variety had very highly significant effect $(\mathrm{P}<0.001)$ on the percent of bulb weight loss of onion in the fourth, sixth and eighth weeks of storage. The effect of intra-row spacing on this quality parameter was also very highly significant $(\mathrm{P}<0.001)$ in all weeks of bulb storage, except the fourth week. The interaction effect between variety and intra-row spacing was very highly significant $(\mathrm{P}<0.001)$ at the second week, highly significant $(\mathrm{P}<0.01)$ at the fourth and eighth weeks and significant $(\mathrm{P}<0.05)$ at the sixth week (Table 1).

During the storage period, Bombay Red experienced the highest weight loss while the mean weight loss for Melkam was the lowest (Table 4 and 5). An increase in the percent of weight loss in all varieties was observed with an increment in the storage period of the bulb due to increase in water loss. In the second week, Adama Red experienced the highest weight loss (5.89\%) with $12.5 \mathrm{~cm}$ intra-row spacing followed by Bombay Red $(4.11 \%)$ with intra-row spacing of $10 \mathrm{~cm}$. Adama Red had the lowest weight loss $(1.65,2.69$ and $2.13 \%)$ with $5,7.5$ and $10 \mathrm{~cm}$ intra-row spacing followed by Melkam (2.90\%) with $7.5 \mathrm{~cm}$ spacing. The loss of weight in the fourth week of storage was highest (8.77 and 8.66\%) for Bombay Red and Shendi with 12.5 and $10 \mathrm{~cm}$ spacing, respectively while Adama Red and Melkam had the lowest loss of weight (4.81 and $4.75 \%$, respectively). At the sixth and eighth weeks of storage, the loss of weight was highest (15.61 and 21.92, respectively) for Bombay Red with $12.5 \mathrm{~cm}$ intra-row spacing, however it was least (9.72 and $12.83 \%)$ for Melkam with intra-row spacing of 10 and $12.5 \mathrm{~cm}$, respectively. In addition, the least weight loss $(9.15 \%)$ was recorded for Adama Red at $5 \mathrm{~cm}$ spacing at the sixth week of bulb storage. Kahsay et al. (2013) also reported that Bombay Red variety showed significantly highest percent of bulb weight loss.

The highest weight loss was recorded at the widest spacing due to high loss of water from bulbs with higher surface area to volume ratio. Asres (2017) reported that higher weight loss during the $12^{\text {th }}$ week of storage was observed in wider spacing $(15 \mathrm{~cm})$ than in bulbs from narrower spacing treatments. Sing and Sing (2003) also reported that larger size bulbs exhibited the highest weight loss compared to smaller sized bulbs.

\section{Correlation Analysis}

According to Table 2, total soluble solid negatively and significantly correlated with bulb diameter $\left(\mathrm{r}=-0.635^{* *}\right)$ and weight loss $\left(\mathrm{r}=-0.565^{* *}\right)$. Positive and highly significant correlation was recorded between neck thickness and bulb diameter $(\mathrm{r}=0.662 * *)$, bulb length $\left(\mathrm{r}=0.621^{* *}\right)$ as well as mean bulb fresh weight $(\mathrm{r}=$ $\left.0.657^{*}\right)$. Bulb diameter had positive and significant, highly significant and very highly significant correlation with bulb length $\left(r=0.524^{*}\right)$ and mean bulb fresh weight $\left(\mathrm{r}=0.896^{* * *}\right)$. Total soluble solid had positive and significant correlation with bulb dry matter content $(\mathrm{r}=0.527 *)$. The relationship between bulb dry matter content and weight loss during the fourth week of storage had been negative and highly significant ( $\mathrm{r}=-0.609 * *)$.

\section{Conclusion}

In this study, most of the quality parameters have been maximized by using Melkam variety with the widest intrarow spacing of 10 and $12.5 \mathrm{~cm}$. However, the total bulb yield will be reduced at the widest intra-row spacing due to low population density. The average bulb weight which is considered as the most important parameter for producers from the marketability point of view did not show significant variation between $7.5 \mathrm{~cm}$ and $10.00 \mathrm{~cm}$ intrarow spacing. Therefore, quality bulb production can be optimized using variety Melkam and $7.5 \mathrm{~cm}$ intra-row spacing and can be recommended to Antsokia Gemza district and other areas with similar agro-ecology.

\section{Acknowledgment}

The authors would like thank to Antsokia Gemza district Office of Agriculture for the field facilities, to Bureau of Agriculture of Amahara National Regional State for financial support and to Melkasa Agricultural Research Center for providing the seeds.

\section{References}

AGWARDO (Antsokia Gemza Woreda Agriculture and Rural Development Office). 2017. Annual crop production report (Unpublished). Antsokia, Ethiopia.

Anisuzzaman M, Ashrafuzzaman M, Ismail MR, Uddin MK, Rahim MA. 2009. Planting time and mulching effect on onion development and seed production. Afr. J. Biotechnol, 8(3): 412-416.

Asres D. 2017. Farmyard manure and intra-row spacing on yield and yield components of Adama Red onion (Allium cepa L.) cultivar under irrigation in Gewane District, Afar Region, Ethiopia. Journal of Horticulture and Forestry, 9(5):40-48.

Awas G, Abdisa T, Tolesa K, Chali A. 2010. Effect of intra-row spacing on yield of three onion (Allium cepa $\mathrm{L}$.) varieties at Adami Tulu Agricultural Research Center (mid rift valley of Ethiopia). Journal of Horticulture and Forestry, 2(1):007-011.

Bagali AN, Patil HB, Guled MB, Patil RV. 2012. Effect of scheduling of drip irrigation on growth, yield and water use efficiency of onion (Allium cepa L.). Karnataka Journal of Agricultural Sciences, 25 (1):116-119.

CSA (Central Statistics Agency). 2016. Area and production of major crops. Ethiopian Agricultural Sample Survey 2015/2016, private peasant holdings, Meher season, Addis Abeba, Ethiopia. https://www.csa.gov.et

Dawar NM, Wazir FK, Dawar M, Dawar SH. 2007. Effect of planting density on growth and yield of onion varieties under climatic conditions of Peshawar. Sarhad Journal of Agriculture, 23(4):911-918.

Demisie R, Tolessa K. 2018. Growth and bulb yield of onion (Allium cepa L.) in response to plant density and variety in Jimma, South Western Ethiopia. Advances in Crop Science and Technology, 6:357. doi: 10.4172/2329-8863.1000357

EARO (Ethiopia Agricultural Research Organization). 2004. Directory of released crop varieties and their recommended cultural practices. Ethiopian Agricultural Research Organization Addis Abeba, Ethiopia. http://www.eiar.gov.et 
ERCA 2017. Ethiopia Revenue and Customs Authority, Import export information. URL: http://www.erca.gov.et/index.php /component/hscode/?view=importexport\&iccaldate=2004-51. Accessed on February 07, 2019.

FAO (Food and Agriculture Organization of United States). 2019. FAOSTAT crop production database, 2017. URL: http://www.fao.org/faostat/en/\#data/QC. Accessed on February 07, 2019.

Grubben JH, Denton DA. 2004. Plant Resources of Tropical Africa 2. Wageningen, Netherlands: PROTA Foundation /Backhuys Publishers, CTA.

HARC (Humera Agricultural Research center). 2018. Onion regional variety trail (Unpublished), Humera, Ethiopia.

Jambo T. 2015. Response of onion (Allium cepa L.) varieties to intra-row spacing at kobo, northern Ethiopia. Msc Thesis, School of Graduate Studies of Alemaya University, Ethiopia

Kahsay Y, Belew D, Abay F. 2013. Effect of intra-row spacing on yield and quality of some onion varieties (Allium cepaL.) at Aksum, Northern Ethiopia. Afr. J. Agric. Res., 7(12): 613622.

Makombe G, Namara R, Hagos F, Awulachew SB, Ayana M. 2011. A comparative analysis of the technical efficiency of rain-fed and smallholder irrigation in Ethiopia. International Water Management Institute. p. 37.
Mallor C, Balcells M, Sales E. 2011. Genetic variation for bulb size, soluble solids content and pungency in the Spanish sweet onion variety Fuentes de Ebro. Response to selection for low pungency. Plant Breeding, 130:55-59.

MARC (Melkassa Agricultural Research Center). 2015. Major Vegetable Crops Production and Management (Tomato, Hot Pepper, Onion and Cabbage). Ethiopian Institute of Agricultural Research, Addis Ababa, Ethiopia. http://www.eiar.gov.et/marc/

Pookpakdi A, Pataradilok H. 1993. Response of genotypes of mung bean and black gram to planting dates and plant population density. Kasetsart Journal (Natural Science), 27:395- 400 .

Rabinowitch HD, Brewster JL. 1990. Onions and Allied crops. Vol. I. Botany, Physiology and Genetics. USA: CRS Press.

SARC (Sirinka Agricultural Research Center). 2008. List of varieties. Sirinka, Ethiopia.

Saud S, Yajun C, Razaq M, Luqman M, Fahad S, Abdullah M, Sadiq A. 2013. Effect of potash levels and row spacing on onion yield. Journal of Biology, Agriculture and Healthcare, 3(16):2013-2118.

Sing AK, Sing V. 2003. Combined effect of set size and planting distance on kharif onion bulb. Indian J. Agr. Res., 37(41):287-290.

Zeleke A, Derso E (Eds). 2015. Production and management of major vegetable crops in Ethiopia. Vol 1. Addis Ababa, Ethiopia: Eth-Cana Printing Press, p. 59 